\title{
Assessment of indicators and collection methodology to estimate nutrient digestibility in buffaloes ${ }^{1}$
}

\section{Luciana Felizardo Pereira Soares ${ }^{2}$, Adriana Guim ${ }^{3}$, Marcelo de Andrade Ferreira ${ }^{3}$, Elisa Cristina Modesto ${ }^{4}$, Ângela Maria Vieira Batista ${ }^{3}$, Paulo de Barros Sales Monteiro ${ }^{2}$}

\author{
1 Projeto financiado pela FACEPE. \\ 2 DZ/UFRPE. \\ ${ }^{3}$ Departmento de Zootecnia/UFRPE. \\ ${ }^{4}$ Instituto de Zootecnia/Departamento de Produção Animal/UFRRJ.
}

\begin{abstract}
Dry fecal matter production was estimated from neutral detergent indicators on indigestible fiber, indigestible acid detergent fiber, indigestible dry matter, incubated for 144 hours and 288 hours, as well as chromium oxide $\left(\mathrm{Cr}_{2} \mathrm{O}_{3}\right)$ and enriched and purified isolated lignin (LIPE $\left.{ }^{\circledR}\right)$ in two sampling schemes ( 3 and 5 days) on buffaloes. Sample consisted of five castrated animals with average weight of $300 \pm 0.6 \mathrm{~kg}$ fed on elephant grass cv Cameroon (Pennisetum purpureum) Experimental design consisted of randomized blocks in subdivided plots. Production of dry fecal matter was overestimated when using $\mathrm{Cr}_{2} \mathrm{O}_{3}$, indigestible acid detergent fiber 144 hours, indigestible neutral detergent fiber 144 hours, indigestible neutral detergent fiber 288 hours and indigestible dry matter 144 hours, while indigestible acid detergent fiber 288 hours, indigestible dry matter 288 hours and LIPE ${ }^{\circledR}$ did not differ from total collection. The same result was observed for apparent digestibility of nutrients. There was no difference in dry fecal matter production and digestibility between both collection periods of 3 and 5 days, demonstrating that a collection period of three days can be used to estimate dry fecal matter production in buffaloes. A three-day period of sample collection, in order to estimate dry fecal matter production and apparent digestibility coefficients, is therefore recommended. The use of LIPE ${ }^{\circledR}$, fibers in indigestible acid detergent and indigestible dry matter as indicators, both latter incubated for 288 hours, result in accurate estimates of dry fecal matter production in confined buffaloes, fed on a forage based diet.
\end{abstract}

Key Words: buffalo, collection period, iADF, LIPE ${ }^{\circledR}$

\section{Introduction}

Indicators are matters that are either indigestible or have known digestibility coefficient, that can be administered with food or directly in some part of the digestive tract for future quantification in the excrements. In order to be validated, methods using indicators always have to be compared to a reference. In the case of the apparent digestibility, this reference is the total fecal matter collection.

Among the existing external indicators, chromium oxide has been more widely used, mainly for fecal production estimations (Valadares Filho et al., 2006). However, some difficulties arise, such as recuperation differing from $100 \%$, variation in fecal recuperation between animals and variable concentrations in the excrements throughout the day (Titgemeyer, 1997). Due to these inconveniences, new indicators have been studied to substitute chromium oxide in digestibility assessments.

LIPE $^{\circledR}$, enriched and purified isolated lignin, developed by researchers of the Departamento de Zootecnia da Escola de Veterinária e de Química do Instituto de Ciências Exatas of Universidade Federal de Minas Gerais, showed to be efficient as digestibility indicator in studies involving several species (Rodriguez et al., 2006).

The internal indicators - indigestible neutral detergent fiber, acid detergent fiber and dry matter have been frequently used. However, precision and accuracy of estimations of digestibility based on these indicators have been variable, possibly resulting from interferences in the quantification process of sampling concentrations (Piaggio et al., 1991).

Long sampling periods need more animal manipulation, more expenses with material to accommodate and preserve the samples and are more labor intensive. Therefore, studies have been carried out to try to determine the smallest period of excrement collection that does not affect the acuity of the sample analyses (Ferreira et al., 2009).

In Brazil, few studies have been carried out in order to estimate digestibility in buffaloes using indicators. Therefore, validation of these methodologies is necessary for this 
animal species. This study aimed at evaluating the use of the indicators indigestible neutral detergent fiber (iNDF), indigestible acid detergent fiber (iADF) and indigestible dry matter (iDM) incubated for 144 hours and 288 hours, chromium oxide and LIPE ${ }^{\circledR}$ to estimate the fecal dry matter production and nutrient digestibility, as well as the period of excrement collection ( 3 and 5 days) in buffaloes.

\section{Material and Methods}

The experiment was carried out in the "Nossa Senhora da Soledade" farm, located in the municipality of Ribeirão, Mata main region and Meridional sub-region of Pernambuco State. The altitude of Ribeirão city is about $97.0 \mathrm{~m}\left(08^{\circ} 30^{\prime} 24^{\prime \prime S}\right.$ $\left.35^{\circ} 22^{\prime} 40^{\prime \prime E}\right), 87.0 \mathrm{~km}$ away from the State capital Recife (CPRH, 2003).

Sample consisted of five castrated male buffaloes of the Murrah race (Bubalus bubalis), with average weight of $300 \pm 0.6 \mathrm{~kg}$, maintained in individual boxes with concrete floor, provided with waterer and brick-made feeders to allow individual consumption assessment. Forage consisted of elephant grass cv Cameroon (Pennisetum purpureum), supplied three times a day (at 7 a.m., 12 a.m. and 5 p.m.). A period of ten days was used for adaptation and consumption registration, allowing 10\% excess, and five days for collection when the forage supplied was equivalent to $90 \%$ of voluntary consumption in order to avoid excess. Forage composition is shown in Table 1. During the collection period, daily forage sampling was carried out in order to obtain a composed sample for each animal and for each collection period (three or five days). These samples were adequately stored in a freezer $\left(-15^{\circ} \mathrm{C}\right)$.

Table 1 - Chemical composition of the supplied forage

\begin{tabular}{lc}
\hline Item & Concentration \\
\hline Dry matter (\%) & 27.73 \\
Organic matter (\% DM) & 92.84 \\
Gross protein (\% DM) & 4.54 \\
Ethereal extract (\% DM) & 1.36 \\
Non-fibrous carbohydrates (\% DM) & 19.01 \\
Neutral detergent fiber, NDF (\% DM) & 67.93 \\
Acid detergent fiber, ADF (\% DM) & 39.87 \\
Indigestible fraction - 144-hour incubation & \\
iNDF (\% DM) & 38.86 \\
iADF (\% DM) & 26.15 \\
iDM (\% DM) & 44.98 \\
Indigestible fraction - 288-hour incubation & \\
iNDF (\% DM) & 35.95 \\
iADF (\% DM) & 22.22 \\
iDM (\% DM) & 40.77 \\
\hline
\end{tabular}

$\mathrm{iADF}=$ indigestible acid detergent fiber; $\mathrm{iNDF}=$ indigestible neutral detergent fiber; iDM = indigestible dry matter.
Total collection of excrements was done directly from box floor. Excrements were gathered in plastic buckets and weighed and homogenized after 24 hours, retaining a sample of $10 \%$ of total daily weight. At the end of the collection period, partial samples for each animal were homogenized to obtain a composed sample for each animal, from which a sample was taken. Afterwards, samples were oven-dried $\left(60^{\circ} \mathrm{C} / 72\right.$ hours $)$ until constant weight, ground and sifted ( $1 \mathrm{~mm}$ riddles). These composed samples were submitted to laboratory analyses.

Twenty grams per day of chromium oxide were added in paper cartridges and supplied in two daily portions with the same weight $(10 \mathrm{~g})$ at $08 \mathrm{a} . \mathrm{m}$. and $4 \mathrm{p} . \mathrm{m}$. for twelve days: seven for adaptation and five for collection. LIPE $^{\circledR}$ was supplied during five days (one capsule of $500 \mathrm{mg} / \mathrm{buffalo} /$ day) at 8 a.m. Chromium oxide and LIPE ${ }^{\circledR}$ capsules have been supplied from the third and tenth day of the experiment, respectively. Excrements have been collected directly from the rectum during the five-day collection period, once a day, in different time schedules (6 a.m., 9 a.m., 12 a.m., 3 p.m. and 6 p.m.). Afterwards, the samples composed were prepared based on air dry weight per animal.

Dry matter (DM), organic matter (OM), gross protein (GP), ethereal extract (EE), mineral matter (MM), neutral detergent fiber (NDF) and acid detergent fiber (ADF) contents were evaluated in the samples according to methods described by Silva \& Queiroz (2002). NDF and ADF contents were assessed by micro extraction in autoclave (Pell \& Schofield, 1993) using non-woven textile bags (NWT $-100 \mathrm{~g} / \mathrm{m}^{2}$; Casali et al., 2009). To quantify the contents of non-fibrous carbohydrates, the following equation was used: $\mathrm{NFC}=100-(\mathrm{NDF}+\mathrm{GP}+\mathrm{EE}+\mathrm{MM})$. To estimate total digestible nutrients (TDN), the equation described by Sniffen et al. (1992) was used: TDN = $\mathrm{TCD}+2.25^{*} \mathrm{EED}+\mathrm{GPD}$ where TCD, EED and GPD mean percentage of total carbohydrates, ethereal extract and digestible gross protein, respectively.

Dry fecal matter production was estimated based on the ratio between quantity of supplied (external indicator) or consumed (internal indicator) indicator and its concentration in the excrements.

In order to quantify concentrations of indigestible ADF, NDF and DM, a $1 \mathrm{~g}$ sample of the forage and $0.5 \mathrm{~g}$ of ground excrements (at $2 \mathrm{~mm}$ ) were put in non-woven textile bags $\left(100 \mathrm{~g} / \mathrm{m}^{2}\right)$ of $4 \times 5 \mathrm{~cm}$, previously identified, dried and weighed, and incubated for 144 and 288 hours in a buffalo rumen, fed on elephant grass. After the incubation period, bags were collected from the rumen, thoroughly washed in flowing water until the water cleared and immediately transferred to the oven for drying $\left(60^{\circ} \mathrm{C} / 72\right.$ hours $)$. Analyses 
were carried out on samples in a non-sequence way with three repetitions for each matter per incubation period and indicator. To quantify residual NDF, bags were boiled in neutral detergent solution for 1 hour, washed with hot water and acetone, dried and weighed, and the residue was considered indigestible NDF. To obtain residual ADF, the same procedure was followed: the bags were washed with acid detergent and the residue was considered indigestible ADF. To estimate DM, bags were dried in a non ventilated oven at $105^{\circ} \mathrm{C}$ for 12 hours and afterwards the indigestible DM was calculated.

Laboratory analyses have been carried out at the Laboratório de Nutrição Animal of Departamento de Zootecnia of Universidade Federal de Rural de Pernambuco. Quantification of chrome concentration in the excrements was made according to methodology described by Fenton \& Fenton (1979), by means of atomic absorption spectrophotometry. LIPE $^{\circledR}$ was analyzed in the Laboratório de Nutrição Animal of the Escola de Veterinária/UFMG, using spectroscopy in the infrared with Fourrier transform in Varian 800. Excrement samples were put directly in the equipment coupled with an ATR. Afterwards, a curve was set up with different LIPE concentrations and then samples were located in this curve relating absorption and excrement concentration.

Experimental design was randomized blocks in subdivided plots, so that plots represent the collection periods ( 3 and 5 days) and the subplots represent the methods (total collection or indicators). Variables were analyzed by following the mathematical model:
$\mathrm{Y}_{\mathrm{ijk}}=\mu+\mathrm{a}_{\mathrm{i}}+\mathrm{p}_{\mathrm{j}}+\mathrm{e}_{\mathrm{ij}}+\mathrm{m}_{\mathrm{k}}+\mathrm{pm}_{\mathrm{jk}}+\varepsilon_{\mathrm{ijk}}$, where $\mu=$ general constant; $a_{i}=$ animal effect or sub-block $\mathrm{i} ; \mathrm{p}_{\mathrm{j}}=$ collection period effect $\mathrm{j} ; \mathrm{e}_{\mathrm{ij}}=$ error; $\mathrm{pm}_{\mathrm{jk}}=$ estimation method effect $\mathrm{j}$ (total collection or indicators); $\mathrm{pm}_{\mathrm{ik}}=$ interaction of period $\mathrm{i}$ and method $\mathrm{k}$; and $\varepsilon_{\mathrm{ijk}}=$ not observable random error, presupposition NID $\left(0 ; \sigma^{2}\right)$. Results were submitted to variance analysis and the means compared by the Dunnett test at $5 \%$ of probability, by means of the Statistical Analysis System (SAS, 1990).

\section{Results and Discussion}

There was no interaction between estimation methods (total collection or indicators) and the collection period $(\mathrm{P}>0.05)$ for fecal DM production, digestibility coefficient of dry matter (DM), ethereal extract (EE), gross protein (GP) or non-fibrous carbohydrates (CNF) (Table 2). However, significant interaction was observed $(\mathrm{P}<0.05)$ between the collection period and the indicators for the organic matter $(\mathrm{OM})$ digestibility coefficient, neutral detergent fiber (NDF) and total digestible nutrients (TDN) (Table 3).

Regardless of the indicator applied, fecal DM production and DM, EE, GP and CNF digestibility did not differ $(\mathrm{P}>0.05)$ when collecting for 3 or five days (Table 2$)$. Ferreira et al. (2009) evaluated internal and external indicators in two schemes of total excrement collection ( 3 or 5 days) for bovines and their results allowed to conclude that 3 collection days are sufficient to obtain accurate estimates of digestibility coefficients.

Table 2 - Fecal dry matter production and nutrient digestibility coefficient estimated by means of indicators in buffaloes

\begin{tabular}{|c|c|c|c|c|c|}
\hline \multirow[t]{2}{*}{ Collection period } & \multirow{2}{*}{$\begin{array}{c}\text { Fecal DM } \\
\text { production } \\
(\mathrm{kg} / \text { day })\end{array}$} & \multicolumn{4}{|c|}{ Digestibility } \\
\hline & & $\begin{array}{c}\text { Dry } \\
\text { matter }(\%)\end{array}$ & $\begin{array}{c}\text { Ethereal } \\
\text { extract }(\%)\end{array}$ & $\begin{array}{c}\text { Non-fibrous } \\
\text { carbohydrates (\%) }\end{array}$ & $\begin{array}{c}\text { Gross } \\
\text { protein }(\%)\end{array}$ \\
\hline 5 days & 2.24 & 41.87 & 39.79 & 95.79 & 32.84 \\
\hline \multicolumn{6}{|l|}{ Indicator } \\
\hline Total collection & 2.01 & 47.29 & 45.35 & 96.25 & 39.50 \\
\hline iDM $^{3} 144$ hours & $2.24 *$ & $41.43^{*}$ & 38.94 & 95.80 & $32.21 *$ \\
\hline iADF 288 hours & 2.01 & 47.46 & 45.12 & 96.23 & 39.27 \\
\hline iNDF 288 hours & $2.24 *$ & $41.45 *$ & 39.09 & 95.82 & $32.41 *$ \\
\hline iDM 288 hours & 2.02 & 47.41 & 41.77 & 96.03 & 35.42 \\
\hline $\mathrm{Cr}_{2} \mathrm{O}_{3}$ & $2.82 *$ & $26.23 *$ & 21.92 & $94.12 *$ & $16.26^{*}$ \\
\hline $\operatorname{LIPE}^{\circledR}$ & 2.08 & 46.08 & 43.50 & 96.22 & 37.14 \\
\hline Collection period $\times$ indicator & 0.3903 & 0.1889 & 0.5131 & 0.7310 & 0.0603 \\
\hline Variation coefficient $(\%)$ & 5.12 & 8.18 & 14.69 & 0.45 & 13.07 \\
\hline
\end{tabular}

$\mathrm{iADF}=$ indigestible acid detergent fiber; $\mathrm{iNDF}=$ indigestible neutral detergent fiber; iDM = indigestible dry matter.

Means in columns followed by $(*)$ differ $(\mathrm{P}<0.05)$ of value obtained for total collection by Dunnett test. 
Fecal DM productions obtained using the indicators iDM 288 hours, iADF 288 hours and LIPE ${ }^{\circledR}$ did not differ $(\mathrm{P}>0.05)$ from total collection (Table 2$)$. However, when using indicators iADF 144 hours, iNDF 144 hours, iNDF 288 hours, iDM 144 hours and chromium oxide, fecal DM production was higher $(\mathrm{P}<0.05)$ than total collection and, consequently, nutrient digestibility was underestimated. According to Berchielli et al. (2005), indicators react differently according to forage, and one of the reasons for this may be the fiber composition of each type of forage, which can affect its rate and extension of degradation. This way, different incubation periods may be necessary depending on the composition of the fiber portion of each type of forage.

Regarding the chromium oxide, the overestimation of the fecal DM production is due to the rate of the flow of this indicator which did not follow the forage flow. According to Ribeiro Filho et al. (2008), the values of recuperation rates of chromium oxide stated in literature may be attributed to differences of kind and quality of diet. For instance, Soares et al. (2004) observed higher recuperation of $\mathrm{Cr}_{2} \mathrm{O}_{3}$ in animals receiving elephant grass of 60-day regrowth with $70 \%$ of NDF comparing to animals receiving the same forage with 30-day regrowth and $63 \%$ of NDF.

Chromium oxide presents some limitations such as the striking variation of its excretion in the feces (Hopper et al., 1978), carcinogenic properties (Peddie et al., 1982), incomplete fecal recuperation (Soares et al., 2004), quicker passage through the rumen than through the fiber material, accumulation in some segment of the gastrointestinal tract and incomplete homogenization in ruminal digest (Van Soest, 1994).

Digestibility of DM and GP calculated from the fecal production obtained by iADF 288 hours, iDM 288 hours and LIPE $^{\circledR}$ did not differ $(\mathrm{P}>0.05)$ from total collection. However, when calculating these nutrients digestibility from the indicators iADF 144 hours, iNDF 144 hours, iNDF 288 hours, iDM 144 hours and chromium oxide, digestibility showed lower values $(\mathrm{P}<0.05)$ when compared to total collection.

The lowest values for nutrient digestibility were obtained using chromium oxide, iNDF, iADF and iDM incubated for 144 hours. This short period of incubation may not be sufficient to reproduce the indigestible portion of the nutrient, as internal indicators need more incubation time to have real reproduction of digestibility (Van Soest, 1994).

It is worth noting that ruminal incubation time is one of the most influencing variables on the representativeness of indigested residues of in situ incubation procedures. The indigestible portion constitutes asymptotic concept, this is, it represents the portion that cannot be used by microbial and animal enzymatic systems when there is no time limitation of exposure to these systems (Paulino et al., 2006).

Therefore, Casali et al. (2008) confirmed that the real value of indigestible portion can only be truly measured in procedures considering infinite time scale. Nevertheless, in practical terms, in situ procedures are based on finite time scales, assuming the timing interval relatively long so that obtained estimates (indigested residue) approach the asymptotic concept (indigestible residue). This way, incubation for 144 hours may not result in adequate estimates of total indigestible portion.

The results obtained in this study support those described by Saliba et al. (1999), who compared several internal and external indicators with the total excrement collection and confirmed that the average obtained with iADF was closer to total collection, demonstrating its high potential as an indicator for forages due to its low cost and easy methodology. Additionally, Oliveira Júnior et al.(2004), when evaluating indicators for nutrient digestibility in bullocks, observed that iNDF overestimated fecal

Table 3 - Average nutrient digestibility coefficient estimated by means of indicators in buffaloes

\begin{tabular}{|c|c|c|c|c|c|c|c|c|c|}
\hline & $\begin{array}{c}\text { Total } \\
\text { carbohydrates }\end{array}$ & $\begin{array}{c}\text { iADF } 144 \\
\text { hours }\end{array}$ & $\begin{array}{c}\text { iNDF } 144 \\
\text { hours }\end{array}$ & $\begin{array}{c}\text { iDM } 144 \\
\text { hours }\end{array}$ & $\begin{array}{c}\text { iADF } 288 \\
\text { hours }\end{array}$ & $\begin{array}{c}\text { iNDF } 288 \\
\text { hours }\end{array}$ & $\begin{array}{c}\text { iDM } 288 \\
\text { hours }\end{array}$ & $\mathrm{Cr}_{2} \mathrm{O}_{3}$ & $\operatorname{LIPE}^{\circledR}$ \\
\hline \multicolumn{10}{|c|}{ Collection period } \\
\hline 3 days & $50.83 \mathrm{a}$ & $45.33 \mathrm{a}$ & $43.64 \mathrm{a}$ & $45.25 \mathrm{a}$ & $49.95 \mathrm{a}$ & $43.47 \mathrm{a}$ & $42.96 \mathrm{a}$ & $32.91 * \mathrm{a}$ & $48.21 \mathrm{a}$ \\
\hline \multirow[t]{2}{*}{5 days } & 48.82 a & $44.21 \mathrm{a}$ & $44.42 \mathrm{a}$ & $42.33 * \mathrm{a}$ & $49.32 \mathrm{a}$ & $44.50 \mathrm{a}$ & $49.96 \mathrm{a}$ & $27.10 * b$ & $47.37 \mathrm{a}$ \\
\hline & \multicolumn{9}{|c|}{ NDF digestibility (\%) } \\
\hline 5 days & \multicolumn{9}{|c|}{ TDN $(\%)$} \\
\hline 3 days & $47.98 \mathrm{a}$ & $42.78 \mathrm{a}$ & $41.18 \mathrm{a}$ & $42.70 \mathrm{a}$ & $47.15 \mathrm{a}$ & $41.02 \mathrm{a}$ & $40.53 * b$ & $32.26 * a$ & $45.51 \mathrm{a}$ \\
\hline 5 days & $46.09 \mathrm{a}$ & $41.71 \mathrm{a}$ & $41.64 \mathrm{a}$ & $39.94 * \mathrm{a}$ & $46.55 \mathrm{a}$ & $41.99 \mathrm{a}$ & $47.16 \mathrm{a}$ & $25.58 * b$ & $44.72 \mathrm{a}$ \\
\hline
\end{tabular}

Means in lines followed by $(*)$ differ from total collection by Dunnett test $(\mathrm{P}<0.05)$. Means in columns, within each variable, followed by different letters differ $(\mathrm{P}<0.05)$ by $\mathrm{F}$ test.

$\mathrm{iADF}=$ indigestible acid detergent fiber; $\mathrm{iNDF}=$ indigestible neutral detergent fiber; iDM $=$ indigestible dry matter. 
production in relation to total collection and underestimated nutrient digestibility.

The mean digestibility values of OM and NDF and the content of TDN observed in the interaction $(\mathrm{P}<0.05)$ of the variables collection period and indicators are presented in Table 3. It can be observed that digestibility estimated by the indicators did not differ from the collection period $(\mathrm{P}>0.05)$, except for iDM 288 hours, which showed higher digestibility values when using a five-day collection period. However, this digestibility did not differ from the one calculated by the total collection method, and chromium oxide, which differed between collection periods and total excrement collection.

Huhtanen et al. (1994) stated that, although the use of iDM as an indicator may produce accurate results, the presence of contaminants, such as microbial residues, can affect the obtained results. The washing of the bags with detergent after incubation allows the removal of microbial residues that fix to the fiber through anionic action (Van Soest, 1994).

Digestibility of organic matter, neutral detergent fiber and of total digestible nutrients, when estimated by iNDF incubated for 144 and 288 hours differed from total collection $(\mathrm{P}<0.05)$. These results support those observed by Freitas et al. (2002), that did not obtain efficient results either, using iNDF, since digestibility values were underestimated.

According to Ítavo et al. (2002), the presence of hemicelluloses can be responsible for the variations observed in studies evaluating iNDF as indicator and results using iADF are less variable.

Casali et al. (2008), evaluating the particle size on the indigestible compounds estimates $\mathrm{iDM}$, iNDF and iADF in bovine feeds and excrements, described that, in general, the occurrence of significant particle size effects was more observed in fibrous feed compared to concentrated feed and excrements. Despite composing the samples with higher lignifications, excrements constitute relapsing material to the ruminal environment implying different characteristics of the fibrous feed and justifying different responses. However, the particle size $(2 \mathrm{~mm})$ used in this study is in accordance with that recommended by Casali et al. (2008), in order to obtain higher estimate precision.

Based on the results obtained, LIPE $^{\circledR}$ can be used to estimate fecal production and digestibility in buffaloes. However, the choice of the external indicator will depend on availability, simplicity of analysis and cost. Regarding the internal indicators, iADF 228 hours and iDM 288 hours can be used in digestibility experiments. A three-day collection period allows reducing animal stress as well as the cost of external indicators, feed, labor and reduction of sample number. However, this study is limited, since only one kind of feed was evaluated.

\section{Conclusions}

A three-day sample collection period is recommended to estimate fecal dry matter production and apparent digestibility coefficients. The use of LIPE ${ }^{\circledR}$, indigestible acid detergent fiber and indigestible dry matter, incubated for 288 hours, as indicators, enables accurate estimates of fecal dry matter production in confined buffaloes fed on forage.

\section{References}

BERCHIELli, T.T.; OLIVEIRA, S.G.; MARTINS, E.N.V. et al. Comparação de marcadores para estimativas de produção fecal e de fluxo de digesta em bovinos. Revista Brasileira de Zootecnia, v.34, n.3, p.987-996, 2005.

CASALI, A.O.; DETMANN, E.; VALADARES FILHO, S.C. et al. Estimação de teores de componentes fibrosos em alimentos para ruminantes em sacos de diferentes tecidos. Revista Brasileira de Zootecnia, v.38, n.1, p.130-138, 2009.

CASALI, A.O.; DETMANN, E.; VALADARES FILHO, S.C. et al. Influência do tempo de incubação e do tamanho de partículas sobre os teores de compostos indigestíveis em alimentos e fezes bovinas obtidos por procedimentos in situ. Revista Brasileira de Zootecnia, v. 37, n.2, p.335-342, 2008.

COMPANHIA PERNAMBUCANA DO MEIO AMBIENTE - CPRH. Diagnóstico socioambiental do litoral Sul de Pernambuco. Recife: 2003. 87p.

FENTON, T.W.; FENTON, M. An improved procedure for the determination of chromic oxide in feed and feces. Canadian Journal of Animal Science, v.59, n.3, p.631, 1979.

FERREIRA, M.A.; VALADARES FILHO, S.C.; MARCONDES, M.I. et al. Avaliação de indicadores em estudos com ruminantes: digestibilidade. Revista Brasileira de Zootecnia, v.38, n.8, p. 1568-1573, 2009.

FREITAS, D.; BERCHIELLI, T.T.; SILVEIRA, R.N. et al. Produção fecal e fluxo duodenal de matéria seca e matéria orgânica estimados por meio de indicadores. Revista Brasileira de Zootecnia, v.31, n.3, p.1521-1530, 2002 (supl.).

ÍTAVO, L.C.V.; VALADARES FILHO, S.C.; SILVA, F.F. et al. Consumo, degradabilidade ruminal e digestibilidade aparente de fenos de gramíneas do gênero Cynodon e rações concentradas utilizando indicadores internos. Revista Brasileira de Zootecnia, v.31, n.2, p.1024-1032, 2002 (supl.).

HOPPER, J.T.; HOLLOWAY, J.W.; BUTTS JUNIOR, W.T. Animal variation in chromiun sesquioxide excretion patterns of grazing cows. Journal Animal Science, v.46, n.4, p.1098-1102, 1978.

HUHTANEN, P.; KAUSTELL, K.; JAAKKOLA, S. The use of internal markers to predict total digestibility and duodenal flow of nutrients in cattle given six different diets. Animal Feed Science and Technology, v.48, n.1, p.211-227, 1994.

OLIVEIRA JÚNIOR, R.C.; PIRES, A.V.P.; FERNANDES, J.J.R. Avaliação de indicadores para estimar a digestibilidade dos nutrientes em novilhos nelore alimentados com dietas contendo alto teor de concentrado e fontes nitrogenadas. Revista Brasileira de Zootecnia, v.33, n.3, p.749-758, 2004.

PAULINO, M.F.; DETMANN, E.; VALADARES FILHO, S.C. Suplementação animal em pasto: energética ou proteica? In: SIMPÓSIO SOBRE MANEJO ESTRATÉGICO DA PASTAGEM, 3., 2006, Viçosa, MG. Anais... Viçosa, MG: SIMFOR, 2006. p.359-392.

PEDDIE, J.; DEWAR, W.A.; GILBERT, A.B. et al. The use of titanium dioxide for determining apparent digestibility in mature domestic fowls (Gallus domesticus). Journal of Agriculture Science, v.99, p.233-263, 1982. 
PELL, A.N.; SCHOFIELD, P. Computerized monitoring of gas production to measure forage digestion in vitro. Journal of Dairy Science, v.76, n.9, p.1063-1073, 1993.

PIAGGIO, L.M; PRATES, E.R.; PIRES, F.F. et al. Avaliação das cinzas insolúveis em ácido, fibra, em detergente ácido indigestível e lignina em detergente ácido indigestível com indicadores internos da digestibilidade. Revista da Sociedade Brasileira de Zootecnia, v.20, n.3, p.306-312, 1991.

RIBEIRO FILHO, H.M.N.; ZIMERMANN, F.C.; KOZLOSKI, G.V. Baixa dosagem de óxido de cromo para estimativa da produção fecal em bovinos. Ciência Rural, v.38, n.9, p.2567-2578, 2008 .

RODRIGUEZ, N.M.; SALIBA, E.O.S.; GUIMARÃES JÚNIOR, R. Uso de indicadores para estimativa de consumo a pasto e digestibilidade. In: REUNIÃO ANUAL DA SBZ, 43., 2006, João Pessoa. Anais... João Pessoa: SBZ, 2006. (CD-ROM).

SALIBA, E.O.S.; RODRÍGUEZ, N.M.; GONÇALVES, L.C. Estudo comparativo da lignina isolada da palha de milho, com outros indicadores em ensaio de digestibilidade aparente. In: REUNIÃO ANUAL DA SOCIEDADE BRASILEIRA DE ZOOTECNIA, 36., 1999, Porto Alegre. Anais... Porto Alegre, 1999. p.293.

SNIFFEN, C.J; O'CONNOR, J.D.; VAN SOEST, P.J. et al. A net carbohydrate and protein system for evaluating cattle diets: II.
Carbohydrate and protein availability. Journal of Animal Science, v.70, n.12, p.3562-3577, 1992

SILVA, D.J.; QUEIROZ, A.C. Análise de alimentos: métodos químicos e biológicos. 3.ed. Viçosa, MG: UFV, Imprensa Universitária, 2002. 235p.

SOARES, L.P.G.; BERCHIELLI, T.T.; AROEIRA, L.J.M Estimativas de consumo do capim-elefante (Pennisetum purpureum Schum), fornecido picado para vacas lactantes utilizando a técnica do óxido crômico. Revista Brasileira de Zootecnia, v.33, n.3, p.811-820, 2004.

STATISTICAL ANALYSIS SYSTEMS - SAS. SAS user's guide: Statistics Version, 1990. SAS, Cary, N.C.

TITGEMEYER, E.C. Design and interpretation of nutrient digestion studies. Journal of Animal Science, v.75, n.8, p.2235-2247, 1997

VALADARES FILHO, S.C.; MORAES, E.H.B.; DETMANN, E. et al. Perspectivas do uso de indicadores para estimar o consumo individual de bovinos alimentados em grupo. In: REUNIÃO ANUAL DA SOCIEDADE BRASILEIRA DE ZooteCniA, 43., 2006, João Pessoa. Anais... João Pessoa, [2006]. (CD-ROM).

VAN SOEST, P.J. Nutritional ecology of the ruminant. 2.ed. Ithaca: Cornell University, 1994. 476p. 